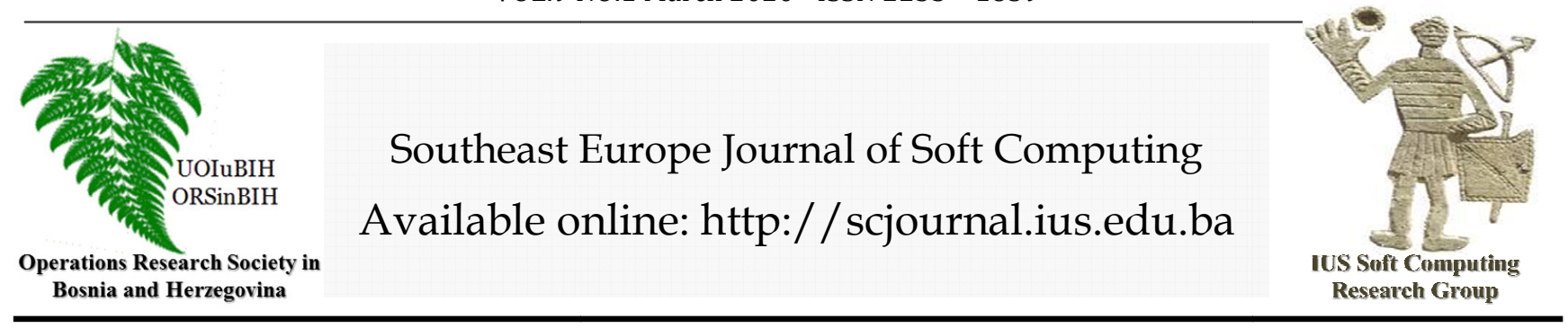

\title{
Efficiency And Productivity Analysis In Turkish Banking Sector With Data Envelopment Analysis And Malmquist Index
}

E. Balc1

B. Ayvaz

Istanbul Commerce University

Küçükyalı E5 Kavşağı İnönü Cad.

No: 4, Küçükyalı 34840 / İstanbul

eminebalci@outlook.com

bayvaz@ticaret.edu.tr

\author{
Article Info \\ Article history: \\ Article received on 10 June 2018 \\ Received in revised form 1 August 2018 \\ Keywords: \\ Banking Efficiency, Data Envelopment Analysis, \\ CCR Model, Malmquist Index
}

\begin{abstract}
The aim of this study is to analyze the efficiency and productivity of 3 public, 6 private and 6 foreign deposit banks operating in the Turkish banking sector with the help of data envelopment analysis and Malmquist index.For this purpose, the efficiency of 15 deposit banks operating in the Turkish banking sector between 2014 and 2018 was measured and whether the efficiency of Malmquist productivity index changed over the years. In the study, input-oriented Charnes Cooper and Rhodes (CCR) model was used under the assumption of constant return to scale and 4 input 2 output variables were selected. Inputs in efficiency and productivity measurement are defined as; personnel expenses / total assets (\%), total loans / total assets (\%), equity / total assets (\%), total deposits / total assets (\%), outputs are defined as; the earning power of assets (net profit / total assets), the earning power of equity (net profit / equity) (\%). The Windows Data Envelopment Analysis Program (Win4Deap) package program was used in the analysis and brokerage approach was adopted. While 4 banks were active under the Constant Return to Scale(CRS) assumption between 2014 and 2018, 8 banks were found active under the assumption of Variable Return to Scale (VRS).Inefficient banks; target values were calculated by slacks movement and radial movement values to their original values and it was found that the lambda values calculated by Win4Deap program and which banks are peers. The changes observed in Malmquist total factor productivity, technical efficiency, technological efficiency, pure efficiency, scale efficiency and total factor productivity were analyzed as a whole and decision-making units experienced improvement in the 2016-2017 period.
\end{abstract}

\section{INTRODUCTION}

Banks play a major role in the development of national economies; however, despite the fact that the banking sector is of great importance in the economic development, financial ratios are indeed very significant for banks to evaluate their performance. In recent years, the concept of efficiency has been therefore one of the top priorities for banks.For its proportional convenience to the analysis and its structure that allows multiple inputs and outputs independent from measurement units, the data envelopment
In the literature, the concepts of efficiency and productivity are often confused. Productivity is defined as the ratio between the quantity of goods and services produced and the inputs used to produce those quantities of goods and services, and is generally formulated as output/input [43].Efficiency, in the economic literature,can be described as the capacity to achieve maximum results with minimum effort or cost, and in the organizational sense, it is defined as the most accurate way of doing things through an inputoutput mechanism [5].Another definition of efficiency 
measurement is to compare the business with its similar production companies[8].

The study starts with literature review and data envelopment analysis models to be applied in the methodology section are explained. In the application part, analysis of the methods mentioned in the methodology was done by using the Win4Deap package program, the results of the program were included in the findings section and their comments were included as well. As a result, the comments on the results of analysis of 15 commercial banks operating in Turkey were discussed and the conclusions were reached.

\section{LITERATURE REVIEW}

It is analyzed[39] that the efficiency of 14 bank branches in the United States and,by conducting with data envelopment analysis, they found that the input variables were based on the personnel employed in each bank branch, branch leasing cost and personnel expenses, and output variables as the number of transactions performed in each branch. Their work yielded that measuring the effectiveness of bank branches revealed that analytical techniques that provide information beyond financial ratios analysis can be obtained and show that data envelopment analysis is a useful complement to other techniques in order to increase bank branch efficiency.

In this paper[9],Boston Consulting Group (BCG) matrix approach is used to measure the corporate performance and competition level of 144 banks operating in Brazil and to classify various operational efficiency and profitability indicators. To this end, banks were initially divided into three groups as large, medium and small-scale banks. Total capital, credit, interest and non-interest income as input, and net profit as output. The result shows that large banks have the best performance and small banks have the worst performance.

It is conducted [29] in the United Statesthatefficiency analysis on the profitability and marketability of 245 major banks, both input-oriented CCR and input-oriented Banker, Charnes, Cooper (BCC). An input-oriented CCR model was used to analyze whether the geographical area of banks had an impact on productivity. Number of employees as input, total assets and shareholders' equity, profit and income as output. The input-oriented BCC model is based on profit and income as input and total earnings of shareholders as output. The conclusion was seen as $14 \%$ of the banks subject to the analysis were those with higher profitability performance but lower marketability performance. The results also show that the geographical position of banks is not related to profitability or marketability efficiency.

It is revealed [4]that 44 commercial banks with public, private and foreign capital belonging to 1999 and 2001 were analyzed. Inputs; deposits, non-deposit resources, equity, interest expenses, non-interest expenses, number of branches and number of personnel, and output; loans were investment. Only the CCR model was used as the method and the results showed that those with public capital are more effective than those with private capital.

In this paper [22], data envelopment analysis is used to analyze the efficiency of the Polish banking industry between 1997 and 2001. As input; number of personnel, deposits and fixed assets, as output; loans, government bonds off - balance sheet expenses. As a result, it is concluded that foreign capital banks are more efficient than Polish banks.

It is found out [2] that the cost and profit efficiency of 28 Chinese commercial banks were examined using a nonparametric technique for data from 1995 to 2004. Tobit examined the impact of ownership type, size, risk profile, profitability and key environmental changes on bank productivity using regression. Inputs; while total deposits, number of personnel and fixed assets, outputs; investments and total loans. It is concluded that profit efficiency levels are below the cost efficiency levels, which shows that the most important inefficiencies are on the income side. Medium-sized banks are the most productive.

It is observed[30] on an analysis of 12 commercial banks in Brazil, using the output-oriented BCC method. The aim is to verify whether the largest commercial banks are also the most efficient in terms of using their resources. The study is an operational research technique based on linear programming aiming to analyze independent units comparatively. It has been concluded that the productivity of the big banks does not play a key role. Equity, total assets and total deposits are taken into consideration while net income is determined as input.

It is put forward [17] that Slacks-based Measure (SBM), slip-based measure and data envelopment analysis were conducted in the efficiency of Japanese banking sector by using profit-return approach as well as mediation and production approaches. Input variables were taken as total deposits, total operating expense, total provision, noninterest expense and other operating expenses, while output variables were taken as total loans, other profitable assets, net commissions, other operating income and net interest income.

In this study [24], it isaimed to measure the effectiveness of 27 public banks operating in India.Data Envelopment Analysis (DEA) was carried out in two stages. As the first stage, the input values were fixed assets, the number of employees and the loanable resources, output values were investments and loans. The input values for the second phase are investments and loans; the output values are net interest income and non-financial income items. That is concluded that only $15 \%$ of the 27 state-owned banks were found to be fully productive, and large-scale banks had lower performance than small-scale banks. Moreover, there is a strong relationship between bank efficiency and bank 
performance, and high efficiency does not mean that banks have high performance.

The effectiveness of 117 branches of a bank in Taiwan is measures according to SBM, CCR, BCC models as determined [27]. It is concluded that the productivity index of big banks is not high.

According to the examination [36], dataenvelopment analysis was conducted in two stages between 2008 and 2003 in deposits of 20 banks in Turkey. Firstly, the efficiency score of the banks was calculated and then the important factors were determined using the balance sheet financial ratios. The main feature that distinguishes the study from other studies is that the inputs and outputs are determined through financial statement analysis such as capital adequacy ratios, balance sheet structural ratios, asset quality ratios, liquidity ratios and profitability ratios. Results were obtained and it is concluded that total credits / total deposits are the most important factors in efficiency measurement.

The efficiency of 11 deposit banks traded on Borsa Istanbul (BIST) between 2013, 2007 and 2011 is measured using the Malmquist Index Method [1]. Input variables are deposits, equity, interest expenses and net profit while interest income items are used as output variables. In which years the selected banks were more effective was researched.

In this paper [32], Czech banking productivity from 2003 to 2012, and SBM, CCR and BCC analyzes are applied. Deposit and personnel expenses were used as input and loans and net interest income as output. The average productivity for the CCR model was between $70 \%$ and $78 \%$; For the BCC model, an average productivity value of $84 \%$ to $89 \%$ was found. The most productive bank was GE Money Bank and the lowest productive bank was CSOB. The reasons for inproductivity of the large group of banks are the excess deposits in the balance sheet and the unsuitable size of the enterprise.

The examination measures [38] theefficiency of Czech Banking between 2003 and 2012; By applying SBM, CCR and BCC analyzes, deposit and personnel expenses were taken as input and loans and net interest income were taken as outputs. The average efficiency for the CCR model was between $70 \%$ and $78 \%$; For the BCC model, an average efficiency value of $84 \%$ to $89 \%$ was found. The most efficient bank was observed as GE Money Bank and the most inefficient bank was seen CSOB. The reasons for inefficiency of the large group of banks are the excess deposits in the balance sheet and the unsuitable size of the enterprise.

In this research [40], it isconduct to analyze the productivity of 40 banks in Brazil, productivity measurement was carried out in two stages. In the first stage, the input values were taken as the number of branches and personnel, while the output value is taken as administrative expenses,and personnel expenses, in the second stage the input values are administrative expenses,and personnel expenses and the output values are equity and fixed assets.

This paper [34] finds that the economic, social,and general productivity of banks in Spain for 2000-2011; provides unique information on stakeholder management banking literature. In conclusion, the study emphasizes that savings banks have played an important role in Spanish culture in the last century and the importance of achieving long-term productivity gains to support financial stability targets.

The efficiency of 16 banks in 2012 in Slovakia is analyzed[44]. 3 different data envelopment analyzes are performed for productivity analysis. These wereBCC, SBM, and super productive SBM models. The main feature that distinguishes the study from the previous literature is to extend the implementation of the BCC and SBM model by the super productive SBM model, which can also list the productive units. More than half of the banks analyzed in the study were able to convert their fixed values to profit and a proposal was made for the banks with low efficiency. The first of these; the management of the lowest performing banking institutions should change their managerial procedures and adopt an improved incentive policy, and the latter should envisage the efforts of the banking institutions licensed by the local central bank to become a branch of a foreign bank.

This paper [22] examinethe efficiency levels of the Gulf Cooperation Council (GCC) banks in terms of technical efficiency (TE), pure technical efficiency (PTE) and scale efficiency (SE). Both PTE and SE represent potential factors that affect the efficiency of GCC banks. The study focuses on the efficiency of a total of 43 GCC banks between 2007 and 2011. Data Envelopment Analysis, which is a nonparametric method within the scope of BCC model, was applied as the total sum of the balance sheet as input for the research and as credit and net profit as deposit output. On average, the results show that GCC Banks operate at an optimal scale, and the results suggest that, despite the increase in technical efficiency resources or management efficiency to $83.6 \%$ in 2011 , there is an administrative inability to use resources. Moreover, the results show that the 22 largest banks tend to operate continuously.

This research in the United States [26] approaches data envelopment analysis from a different perspective, firstly using an input-oriented CCR model and then using the back propagation neural network method. In the first stage, input to the analysis was the number of personnel, shareholders' equity and operating expenses, while the outputs were deposits, loans and investments made during the period. In the second stage, loans and investments during the period were taken as input and net profit was taken as output. The proposed model helps the managerial decision-making process. 
The efficiency of deposit banks and participation banks is examined [42], in order to measure their technical, scale and overall efficiency between 2007 and 2013 and two methods were compared with each other for 4 participations and 28 deposit banks by applying input-oriented CCR and inputoriented BCC method. Deposits and capital are taken as inputs while loans, investments and net profit are considered as output. Because of the theoretical concepts and operational differences, productivity scores can be distinguished in terms of operational and external factors as participation banks and traditional banks perform financially differently. Unlike traditional banks, the unproductivity of participation banks during the period was predominantly scaled. In general, the judiciary concluded that Islamic banks were slightly more productive than other deposit banks.

Fuzzy data envelopment analysis is used [41] to evaluate bank productivity in Mozambique in 2003 and 2011. Inputs were expenses non-personnel expenses and personnel expenses while outputs are total deposit, income before tax and total credit volume. As a result of the analysis, banks should reduce personnel expenses to increase productivity and take initiatives to benefit from capital.

This paper [37] analyzesbank productivity in Vietnam from 1999 to 2009 , a unique study in terms of monitoring the development of the Vietnamese banking industry over the last 10 years. The CCR and BCC methods were used together and, as input, the number of personnel, deposits obtained from other banks and deposits brought by customers are taken while loans, other loans and securities received from customers are used as output. As a result of the analysis, it was concluded that non-state commercial banks are more efficient than state-owned commercial banks. They also concluded that banks with large branch networks and long-standing banks were less productive than others.

The efficiency analysis of participation banks of Southeast Asian countries between 2006 and 2014 is researched by using the BCC and Malmquist panel regression[23].This study, which includes data from 29 Islamic banks active in Brunei, Indonesia and Malaysia, took into account personnel expenses, deposits and fixed assets as input, and loans and investments as output. The productivity level of Islamic banks is evaluated using the Malmquist productivity index method based on data envelopment analysis. A panel regression analysis framework based on the least square was used to identify potential determinants. Capitalization, liquidity and financial crises in the world have a significant effect on the productivity level of participation banks, therefore, it has been proved that the efficiency of participation banks has increased in the years examined.

This examination[21] conductsa research on the efficiency values in the 2012-2016 period and they calculate the values by applying the CCR and BCC models to 37 Brazilian banks. As input variable, while fixed assets, deposits and personnel expenses were taken, total loans were taken as output variables. The study concluded that the largest banks are not the most productive banks. If efficient and smallscale banks are merged, they will have a better future in the banking sector.

It isfound [16] that the productivity of private, public and foreign by capital banks operating in Turkey between 2008 and 2016. CCR and BCC methods were applied separately. Deposits, interest expenses and number of personnel were taken into account as input and loans and interest income were taken into account as output. Two banks were selected as examples and how these banks could be effective was examined.

In the preparation of this examination, it is aimed to reach a conclusion on an analysis on Turkish banks by using both the Turkish and international literature mentioned above. And as a result of the researches, it is revealed that efficiency of banks can be measured by quite different methods. By making a comparison between periods with the help of Malmquist index, the productivity measurement was analyzed, and the efficiency measurement was made with data envelopment analysis.

\section{METHODOLOGY: DATA ENVELOPMENT ANALYSIS AND MALMQUIST TOTAL FACTOR PRODUCTIVITY INDEX}

Data Envelopment Analysis is a mathematical programming technique that measures the efficiency of the decisionmaking unit relative to all other decision-making units with the simple restriction on above or below all decision-making units[35].Data envelopment analysis also identifies sources and unproductivity for each of the inputs and outputs for inefficient decision-making units [10].It is a non-parametric linear programming approach that can handle multiple inputs as well as multiple outputs [3]. Data envelopment analysis calculates the relative productivity of all decisionmaking units relative to all other decision-making units, using the actual observed values for the inputs and outputs. It also defines the level of unproductivity and resources for each of the inputs and outputs for unproductive decisionmaking units[10]. Models can be created to minimize inputs or maximize outputs. Input routing aims to maximize the output levels without increasing input usage, while at least reducing the amount of inputs as much as possible while maintaining the current output levels [15]. 


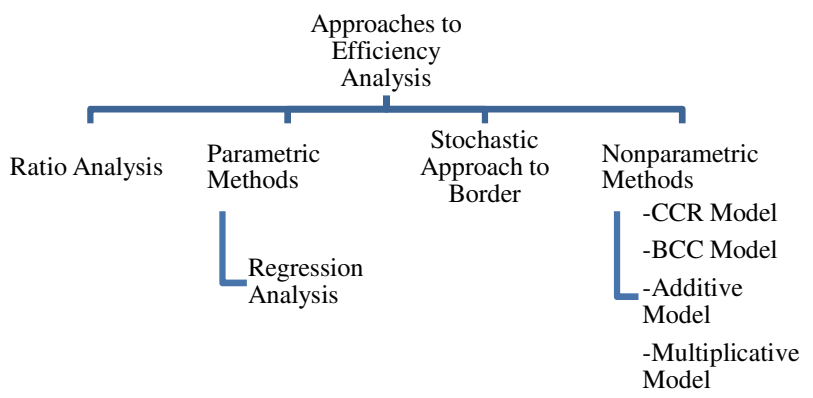

Table 1: Basic Methods in Efficiency Analysis Approach

Under the assumption of constant return to the scale (CRS), the CCR model assumes that there is no significant relationship between enterprise scale and productivity and that it provides overall technical efficiency.The CRS assumption assumes that all decision-making units operate at the optimal scale. Therefore, it may encounter negative economies of scale in decision-making units [12]. When all decision-making units do not operate at an optimal scale, the CRS assumption will disrupt the scale efficiency that extends the CCR model. The only difference between CCR and BCC models i convex restriction. The obtained BCC model is used to evaluate the effectiveness of decision making units characterized by variable return on scale (VRS).

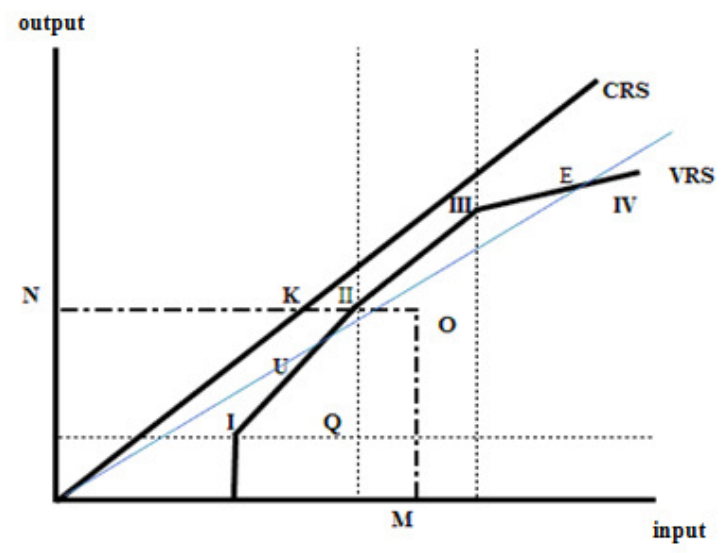

Graph 1: Graphical representation of the assumption of constant returns by scale and variable returns by scale

The figure shows the effective boundary of the correct CRS starting from the origin. The fragmented form passing through I, II, III, IV shows the effective limits of VRS (variable return on scale). III. The decision making unit is the effective decision making unit according to both CRS and VRS. In this case, the following comments can be made according to the graph [13].

If point I shifts to point II, its technical efficiency does not change, but its efficiency increases.
Although the decision unit at point "O" has the same input scale as decision unit III, it produces less output than decision unit III. The "O" point unit operates on an optimum scale but wastes its resources.

If $\mathrm{E}$ decreases its scale, it can provide scale efficiency. Although $\mathrm{U}$ and $\mathrm{E}$ decision units are technically effective, the scale is not effective.

If the $\mathrm{Q}$ decision unit can increase the output level by maintaining the input level and reach the point II, it will be both technical and efficient. If the $\mathrm{Q}$ decision unit manages to produce the same amount of output with less input and can reach point $\mathrm{I}$, it will be both technically efficient and increase efficiency. However, this increase will not be as in point II.

If the decision unit E shifts to point III, it is still technically effective, but it should be scaled down to increase its efficiency.

If the $U$ point enlarges its scale while maintaining its effectiveness and reaches the III point, then both the technique is effective and the scale will be effective.

For a specific decision-making unit under consideration, $\mathrm{k}$, related variables to be used for CCR and BCC models are;

$\mathrm{y}=$ output, $\mathrm{x}=$ input; $\mathrm{u}, \mathrm{v}=$ weights;

$\mathrm{r}=1, \mathrm{~m} ; \mathrm{i}=1, \ldots, \mathrm{n}$;

$\mathrm{j}=1, \ldots \mathrm{K}$

$\mathrm{K}=$ Number of decision-making units, $\mathrm{m}=$ Number of Outputs,

$\mathrm{n}=$ Number of Inputs

$u_{r}=$ Weight calculated for $\mathrm{r}$. output

$v_{i}=$ Weight calculated for $\mathrm{i}$. input

$x_{i j}=\mathrm{j}$. The amount of input used by the decision-making unit

$y_{r j}=$ Amount of $\mathrm{r}$. output generated by the decision-making unit $\mathrm{j}$

$x_{i k}=$ Amount of $\mathrm{i}$. input used by the decision-making unit $\mathrm{k}$.

$y_{r k}=$ Amount of Output generated by decision making unit $\mathrm{k}$

Equations to represent are given below.

\subsection{CCR MODEL}

\subsubsection{Input Oriented CCR Model}

The Inputoriented CCR model, which aims to reduce the amount of input and achieve maximum productivity without changing the output amount; 
$\max \mathrm{Z}=\sum_{r=1}^{m} u_{r} y_{r k}$

Subject to:

$\sum_{i=1}^{n} v_{i} x_{i k}=1$

$\sum_{r=1}^{m} u_{r} y_{r j}-\sum_{i=1}^{n} v_{i} x_{i j} \leq 0, \forall j$

$u_{r} v_{i} \geq 0, \forall r, i$

\subsubsection{Output Oriented CCR Model}

The output oriented CCR model which aims to increase the output amount and get maximum productivity without changing the amount of input;

$\min \mathrm{Z}=\sum_{r=1}^{n} v_{r} x_{r k}$

Subject to:

$\sum_{i=1}^{m} u_{i} y_{i k}=1$

$\sum_{r=1}^{m} u_{r} y_{r j}-\sum_{i=1}^{n} v_{i} x_{i j} \leq 0, \forall j$

$u_{r} v_{i} \geq 0, \forall r, i$

\subsection{BCC MODEL}

The BCC model emerged as a continuation of the CCR model is created[6].In contrast to the CCR model, the BCC model, also known as variable return on scale (VRS), is a general value that combines scale efficiency and technical efficiency. The BCC model measures not only administrative and technical issues, but also pure technical efficiency[27].

\subsubsection{Input-Oriented BCC Model}

The inputoriented BCC model aims to increase pure technical efficiency by trying to minimize inputs.

$\max \mathrm{Z}=\sum_{r=1}^{m} u_{r} y_{r k}-u_{k}$

Subject to:

$$
\begin{aligned}
& \sum_{i=1}^{n} v_{i} x_{i k}=1 \\
& \sum_{r=1}^{m} u_{r} y_{r j}-\sum_{i=1}^{n} v_{i} x_{i j}-u_{k} \leq 0
\end{aligned}
$$

$u_{r} v_{i} \geq 0$

\subsubsection{Output Oriented BCC Model}

It aims to increase the level of pure technical efficiency by increasing the amount of output.

$\min \mathrm{Z}=\sum_{r=1}^{n} v_{r} x_{r k}-v_{k}$

Subject to:

$\sum_{i=1}^{m} v_{i} x_{i k}=1$

$\sum_{r=1}^{m} u_{r} y_{r j}-\sum_{i=1}^{n} v_{i} x_{i j} \leq 0$,

$u_{r} v_{i} \geq 0$

\subsection{Malmquist Total Factor Analysis (MTFA)}

Malmquist total factor productivity analysis is a method used to analyze productivity differences between two firms or over more than one time period of one firm.

The changes observed in the technical efficiency, technological efficiency, pure efficiency, scale efficiency and total factor productivity of the period analyzed by the Malmquist index can be examined as a whole.

MTFP, which defines productivity differences between two firms or between two time periods of one firm and can be calculated as input and output oriented, is based on the change in technical efficiency and technology[19].

The effect of the change in technical efficiency (TEC) production limit is expressed as the displacement of the technological change (TC) production limit[33]. The multiplication of technical efficiency and technological change gives the MTFP index[31].

Malmquist total factor productivity is calculated from the technical and technological efficiency values as it is known and covers the effect of two changes.

Malmquist Total Factor Productivity Index $=($ TEC $) \times($ TC $)$

$\mathrm{M}_{0}^{\mathrm{t}+1}\left(x^{t}, y^{t}, x^{t+1}, y^{t+1}\right)=\frac{D_{0}^{t+1}\left(x^{t+1}, y^{t+1}\right)}{D_{0}^{t}\left(x^{t}, y^{t}\right)} \times \sqrt{\left[\frac{D_{0}^{t}\left(x^{t+1}, y^{t+1}\right)}{D_{0}^{t+1}\left(x^{t+1}, y^{t+1}\right)} \times \frac{D_{0}^{t}\left(x^{t}, y^{t}\right)}{D_{0}^{t+1}\left(x^{t}, y^{t}\right)}\right]}$

-If $M_{0}$ the index is greater than "1"; There is growth in total factor productivity from $t$ period to $t+1$ period.

- If $M_{0}$ the index is less than "1"; There is a decrease in total factor productivity from $t$ period to $t+1$ period.

- If $M_{0}$ the index is equal to "1"; There is no change in total factor productivity from $t$ period to $t+1$ period. 
[13]

Technical efficiency refers to the approach of decisionmaking units to the effective production limit. If the score is greater than 1, this means that the firm has improved towards achieving the production limit.

It shows the shift of the production limit production possibilities curve obtained with technological change over time.

Technical efficiency and technological change values greater than 1.00 indicate positive improvements in period performance. A value less than 1.00 indicates a decline in performance.

It can be stated that the change in pure efficiency level indicates the change in technical efficiency level under the assumption of variable returns according to the scale of decision-making units [28].

Scale effectiveness indicates whether decision-making units use the optimal production scale.

\section{APPLICATION}

\subsection{Determination of Decision Making Units (DMU)}

In this study, 3 public, 6 private and 6 foreign capital banks were determined as decision-making units. In order to ensure that the decision-making units are homogeneous for a total of 15 banks to be analyzed, first of all, expert opinion was taken and 15 deposit banks selected, based on asset size ranking in 2018, were decided to be included in the research. One of the basic principles of data envelopment analysis is the use of DMUs with similar input and output structure. Thus, the system will have a more comparable structure. While choosing DMUs, banks with similar activities and similar targets were preferred for homogeneity to be in the foreground. In this case, the number of DMUs are 15 and the data of banks for the last 5 years has been analyzed. In this system with 4 inputs and 2 outputs, $N$; in a system with DMU number, $-\mathrm{m}$ as input and $\mathrm{s}$ as output- [14]; while $\mathrm{N} \geq$ $\max \{(\mathrm{m} \times \mathrm{s}), 3 \times(\mathrm{m}+\mathrm{s})\}$, the number of DMU is expected to be 18. However, it is based [18] on the formula $\mathrm{N} \geq 2 \times$ $(m+s)$, the number of DMU should be equal or greater than $12(15 \geq 12)$. The reason is that according to Tarım (2001); the reason is that, to get meaningful results, DMUs have to be homogeneous. As the number of banks increases, it was thought that the homogeneous structure would deteriorate and the analysis was carried out according to this framework. There are different opinions in determining the number of DMUs. According to this paper [7], with the equation $\mathrm{N} \geq(\mathrm{m}+\mathrm{s}+1)$, the number of DMUs will be reliable and will be able to achieve an effective result in data envelopment analysis. The determined number of DMUs also supports this view $(15 \geq 7)$.

\subsection{Determination of Input and Output Variables}

4 different input variables and 2 different output variables were used.

\begin{tabular}{|c|c|}
\hline INPUTS & OUTPUTS \\
\hline $\begin{array}{c}\text { Personnel Expenses / Total } \\
\text { Assets }\end{array}$ & \multirow{2}{*}{$\begin{array}{c}\text { ROA = Earnings Power of } \\
\text { Assets (Net Profit / Total } \\
\text { Assets) }\end{array}$} \\
\hline Total Loans / Total Assets & \\
\hline Equity / Total Assets & \multirow{2}{*}{$\begin{array}{c}\text { ROE = Equity Earnings } \\
\text { (Net Profit / Equity) }\end{array}$} \\
\hline $\begin{array}{c}\text { Total Deposits / Total } \\
\text { Assets }\end{array}$ & \\
\hline
\end{tabular}

\section{Table 2: Input and Output variables}

\subsection{Data Collection}

For the 15 banks subjected to analysis; information on net profit, total assets, equity, personnel expenses, total loans, total liabilities and total deposits information were obtained from the financial statements of the 15 banks between the period of 2014-2018 on http://www.tbb.org.tr and http://www.kap.org.tr.

\subsection{Program and Model Selection}

Win4Deap program was used for data envelopment analysis. The aim was to interpret how much input variables could change by assuming that the outputs were under constant returns. Therefore, the input oriented CCR model was preferred as the model. In order to calculate the effectiveness of the scale, the input oriented BCC model was applied under the assumption of variable returns according to the scale and increasing, decreasing and constant return comments were made on the scale return. Then, Malmquist total factor productivity method was applied and the results were examined.

\section{FINDINGS}

According to the analysis results; Akbank, Alternatif Bank, Fibabanka, and Ziraat Bank became the benchmark banks for 4,7,5, and 10 different banks, respectively.

\subsection{CCR analysis and Scale Effectiveness}

The results under the assumption of fixed returns by scale and variable returns by scale are as follows.

".": Constant

IRS:Increased return to scale

DRS: Decreasing return to scale

\begin{tabular}{|c|c|c|c|c|} 
Bank & CRS (TE) & VRS (PTE) & $\begin{array}{c}\text { CRS/VRS( } \\
\text { SE) }\end{array}$ & Scale \\
\hline Akbank & 1.000 & 1.000 & 1.000 & - \\
\hline Alternatif Bank & 1.000 & 1.000 & 1.000 & - \\
\hline Burgan Bank & 0.052 & 0.052 & 0.999 & - \\
\hline Deniz Bank & 0.830 & 1.000 & 0.830 & IRS \\
\hline Fibabanka & 1.000 & 1.000 & 1.000 & - \\
\hline
\end{tabular}


16 E. Balc1, and B. Ayvaz/ Southeast Europe Journal of Soft Computing Vol.9 No.1 March 2020 (9-23)

\begin{tabular}{|c|c|c|c|c|}
\hline ING & 0.398 & 1.000 & 0.398 & IRS \\
\hline Qnb Finansbank & 0.784 & 0.785 & 0.998 & IRS \\
\hline Şekerbank & 0.662 & 0.663 & 0.999 & DRS \\
\hline TEB & 0.772 & 0.773 & 0.999 & DRS \\
\hline Ziraat Bankas1 & 1.000 & 1.000 & 1.000 & - \\
Garanti BBVA & 0.973 & 1.000 & 0.973 & IRS \\
Halk Bankas1 & 0.982 & 0.988 & 0.994 & IRS \\
\hline İş Bankas1 & 0.912 & 0.917 & 0.995 & DRS \\
\hline Vakıfbank & 0.971 & 1.000 & 0.971 & IRS \\
\hline $\begin{array}{c}\text { Yapı Kredi } \\
\text { Bankası } \\
\text { GEOMETRIC } \\
\text { MEAN }\end{array}$ & 0.711 & 0.735 & 0.967 & IRS \\
\hline
\end{tabular}

Table 3: Scale Effectiveness

According to the results of the analysis Akbank, Alternatif Bank, Fibabanka and Ziraat Bank are the most efficiency banks according to CRS column. Other banks in order of descending efficiency; Halk Bankası, Garanti BBVA, Vakıf Bank, İş Bankası, Deniz Bank, Qnb FinansBank, TEB, Yapı Kredi Bankası, Şeker Bank, ING and Burgan Bank.

\section{Burgan Bank}

\begin{tabular}{|c|c|c|c|c|}
$\begin{array}{c}\text { Technical } \\
\text { Efficiency }\end{array}$ & \multicolumn{4}{|c|}{$\mathbf{0 , 0 5 2}$} \\
\hline Variables & $\begin{array}{c}\text { Original } \\
\text { Value }\end{array}$ & $\begin{array}{c}\text { Radial } \\
\text { Movement }\end{array}$ & $\begin{array}{c}\text { Slack } \\
\text { Movement }\end{array}$ & $\begin{array}{c}\text { Projected } \\
\text { Value }\end{array}$ \\
\hline $\begin{array}{c}\text { ROA } \\
\text { ROE }\end{array}$ & 0,001 & 0,000 & 0,000 & 0,001 \\
0,007 & 0,000 & 0,000 & 0,007 \\
\hline $\begin{array}{c}\text { Personnel } \\
\text { Expenses / Total } \\
\text { Assets } \\
\begin{array}{c}\text { Total Loans / } \\
\text { Total Assets }\end{array}\end{array}$ & 0,013 & $-0,012$ & 0,000 & 0,000 \\
\hline $\begin{array}{c}\text { Equity / Total } \\
\text { Assets }\end{array}$ & 0,108 & $-0,102$ & 0,000 & 0,006 \\
\hline $\begin{array}{c}\text { Total Deposits / } \\
\text { Total Assets }\end{array}$ & 0,619 & $-0,586$ & $-0,001$ & 0,031 \\
\hline
\end{tabular}

\begin{tabular}{|c|c|}
\hline Peer & Lambda Weight \\
\hline Ziraat Bankas1 & 0,038 \\
\hline Alternatif Bank & 0,014 \\
\hline
\end{tabular}

Table 4: Burgan Bank CCR analysis

Target Value Calculation;

$(0,038 \times 0,007)+(0,014 \times 0,014)=0,000462 \approx 0,001$ (Personnel Expenses / Total Assets)

$(0.038 \times 0.573)+(0.014 \times 0.74)=0.032134 \approx 0.032($ Total Credits / Total Assets)

$(0.038 \times 0.1115)+(0.014 \times 0.09)=0.00563 \approx 0.006$ (Equity / Total Active)

$(0.038 \times 0.619)+(0.014 \times 0.532)=0.03097 \approx 0.031($ Total Deposits / Total Assets)

In order to for to Burgan Bank to be effective, it should take resemble Ziraat Bankası by \%o 38 and Alternatif Bank by \%o 14.

\section{Deniz Bank}

\begin{tabular}{|c|c|c|c|c|}
\hline \multirow{2}{*}{$\begin{array}{c}\text { Technical } \\
\text { Efficiency }\end{array}$} & \multicolumn{4}{|c|}{$\mathbf{0 , 8 3 0}$} \\
Variables & $\begin{array}{c}\text { Original } \\
\text { Value }\end{array}$ & $\begin{array}{c}\text { Radial } \\
\text { Movement }\end{array}$ & $\begin{array}{c}\text { Slack } \\
\text { Movement }\end{array}$ & $\begin{array}{c}\text { Projected } \\
\text { Value }\end{array}$ \\
\hline ROA & 0,008 & 0,000 & 0,001 & 0,009 \\
\hline ROE & 0,100 & 0,000 & 0,000 & 0,100 \\
\hline $\begin{array}{c}\text { Personnel Expenses } \\
\text { / Total Assets } \\
\text { Total Loans / Total } \\
\text { Assets }\end{array}$ & 0,015 & $-0,002$ & $-0,004$ & 0,008 \\
\hline $\begin{array}{c}\text { Equity / Total } \\
\text { Assets }\end{array}$ & 0,620 & $-0,105$ & 0,000 & 0,515 \\
\hline $\begin{array}{c}\text { Total Deposits / } \\
\text { Total Assets }\end{array}$ & 0,620 & $-0,105$ & $-0,037$ & 0,478 \\
\hline
\end{tabular}

\begin{tabular}{|c|c|}
\hline Peer & Lambda Weight \\
\hline Fibabanka & 0,436 \\
Ziraat Bankas1 & 0,314 \\
\hline
\end{tabular}

Table 5: Deniz Bank CCR analysis

Target Value Calculation;

$(0.436 \times 0.009)+(0.314 \times 0.016) \approx 0.009(\mathrm{ROA})$

$(0,436 \times 0,014)+(0,314 \times 0,007) \approx 0,008$ (Personnel Expenses / Total Assets)

$(0,436 \times 0,770)+(0,314 \times 0,573) \approx 0,515$ (Total Loans / Total Assets)

$(0,436 \times 0,073)+(0,314 \times 0,115) \approx 0,068$ (Own resources / Total assets)

$(0,436 \times 0,652)+(0,314 \times 0,619), 40,478$ (Total Deposits / Total Assets)

In order for to Deniz Bank to be effective, it should take resemble of FibaBanka by \% 44 and Ziraat Bank by $\% 31$.

ING

\begin{tabular}{|c|c|c|c|c|}
\hline Technical Efficiency & \multicolumn{4}{|c|}{0,398} \\
\hline $\begin{array}{c}\text { Variables } \\
\text { ROA }\end{array}$ & $\begin{array}{c}\text { Original } \\
\text { Value } \\
0,005\end{array}$ & $\begin{array}{c}\text { Radial } \\
\text { Movement } \\
0,000\end{array}$ & $\begin{array}{c}\text { Slack } \\
\text { Movement } \\
0,000\end{array}$ & $\begin{array}{c}\text { Projected } \\
\text { Value } \\
0,005\end{array}$ \\
\hline ROE & 0,051 & 0,000 & 0,000 & 0,051 \\
\hline $\begin{array}{c}\text { Personnel Expenses / } \\
\text { Total Assets }\end{array}$ & 0,014 & $-0,008$ & 0,000 & 0,005 \\
\hline $\begin{array}{c}\text { Total Loans / Total } \\
\text { Assets }\end{array}$ & 0,738 & $-0,444$ & $-0,018$ & 0,276 \\
\hline Equity / Total Assets & 0,091 & $-0,055$ & $-0,002$ & 0,034 \\
\hline $\begin{array}{c}\text { Total Deposits / Total } \\
\text { Assets }\end{array}$ & 0,502 & $-0,302$ & 0,000 & 0,200 \\
\hline
\end{tabular}


17 E. Balc1, and B. Ayvaz/ Southeast Europe Journal of Soft Computing Vol.9 No.1 March 2020 (9-23)

\begin{tabular}{|c|c|}
\hline Peer & Lambda Weight \\
Akbank & 0,016 \\
\hline Alternatif Bank & 0,360 \\
\hline
\end{tabular}

Tablo 6: ING CCR analysis

Target Value Calculation;

$(0,016 \times 0,007)+(0,360 \times 0,014) \approx 0,005$ (Personnel Expenses / Total Assets)

$(0,016 \times 0,613)+(0,360 \times 0,740) \approx 0,276$ (Total Loans / Total Assets)

$(0,016 \times 0,122)+(0,360 \times 0,09) \approx 0,034$ (Own resources /

Total Active)

$(0,016 \times 0,552)+(0,360 \times 0,532) \approx 0,200$ (Total Deposits /

Total Assets)

In order for to ING Bank to be effective, it should take resemble of Akbank by \%o 16 and Alternative Bank by \%o 36.

\section{Qnb Finansbank}

\begin{tabular}{|c|c|c|c|c|}
\hline $\begin{array}{c}\text { Technical } \\
\text { Efficiency }\end{array}$ & \multicolumn{4}{|c|}{$\mathbf{0 , 7 8 4}$} \\
\hline Variables & $\begin{array}{c}\text { Original } \\
\text { Value }\end{array}$ & $\begin{array}{c}\text { Radial } \\
\text { Movement }\end{array}$ & $\begin{array}{c}\text { Slack } \\
\text { Movement }\end{array}$ & $\begin{array}{c}\text { Projected } \\
\text { Value }\end{array}$ \\
\hline ROA & 0,012 & 0,000 & 0,000 & 0,012 \\
\hline ROE & 0,102 & 0,000 & 0,000 & 0,102 \\
\hline $\begin{array}{c}\text { Personnel Expenses } \\
\text { / Total Assets }\end{array}$ & 0,013 & $-0,003$ & $-0,003$ & 0,007 \\
\hline $\begin{array}{c}\text { Total Loans / Total } \\
\text { Assets }\end{array}$ & 0,668 & $-0,144$ & $-0,031$ & 0,493 \\
\hline $\begin{array}{c}\text { Equity / Total } \\
\text { Assets }\end{array}$ & 0,114 & $-0,025$ & 0,000 & 0,089 \\
\hline $\begin{array}{c}\text { Total Deposits / } \\
\text { Total Assets }\end{array}$ & 0,559 & $-0,121$ & 0,000 & 0,439 \\
\hline
\end{tabular}

\begin{tabular}{|c|c|}
\hline Peer & Lambda Weight \\
\hline Ziraat Bankası & 0,155 \\
Alternatif Bank & 0,157 \\
\hline Akbank & 0,469 \\
\hline
\end{tabular}

Table 7: Qnb FinansBank CCR analysis

Target Value Calculation;

$(0,155 \times 0,007)+(0,157 \times 0,014)+(0,469 \times 0,007) \approx 0,007$ (Personnel Expenses / Total Assets)

$(0,155 \times 0,573)+(0,157 \times 0,740)+(0,469 \times 0,613), 60,613$

(Total Loans / Total Assets)

$(0,155 \times 0,115)+(0,157 \times 0,090)+(0,469 \times 0,122) \approx 0,122$

(Own resources / Total Active)

$(0,155 \times 0,619)+(0,157 \times 0,532)+(0,469 \times 0,552) \approx 0,552$

(Total Deposits / Total Assets)

In order for to QNB FinansBank to be effective, it should take resemble of Ziraat Bank by, \%16 to Alternatif Bank $\% 16$ and Akbank by $\% 47$.

\begin{tabular}{|c|c|c|c|c|}
\hline $\begin{array}{r}\text { Şeker Bank } \\
\text { Technical } \\
\text { Efficiency }\end{array}$ & \multicolumn{4}{|c|}{0,662} \\
\hline Variables & $\begin{array}{l}\text { Original } \\
\text { Value }\end{array}$ & \begin{tabular}{c|} 
Radial \\
Movement
\end{tabular} & $\begin{array}{c}\text { Slack } \\
\text { Movement }\end{array}$ & $\begin{array}{c}\text { Projected } \\
\text { Value }\end{array}$ \\
\hline ROA & 0,011 & 0,000 & 0,000 & 0,011 \\
\hline ROE & 0,094 & 0,000 & 0,000 & 0,094 \\
\hline $\begin{array}{c}\text { Personnel Expenses } \\
\text { / Total Assets }\end{array}$ & 0,016 & $-0,005$ & $-0,005$ & 0,005 \\
\hline $\begin{array}{c}\text { Total Loans / Total } \\
\text { Assets }\end{array}$ & 0,691 & $-0,233$ & $-0,066$ & 0,391 \\
\hline $\begin{array}{c}\text { Equity / Total } \\
\text { Assets }\end{array}$ & 0,113 & $-0,038$ & 0,000 & 0,075 \\
\hline $\begin{array}{c}\text { Total Deposits / } \\
\text { Total Assets }\end{array}$ & 0,639 & $-0,216$ & $-0,019$ & 0,405 \\
\hline
\end{tabular}

\begin{tabular}{|c|c|}
\hline Peer & Lambda Weight \\
Ziraat Bankası & 0,597 \\
\hline Alternatif Bank & 0,066 \\
\hline
\end{tabular}

Table 8: Şeker Bank CCR analysis

Target Value Calculation;

$(0,597 \times 0,007)+(0,066 \times 0,014) \approx 0,005$ (Personnel Expenses / Total Assets)

$(0,597 \times 0,573)+(0,066 \times 0,74), 30,391$ (Total Loans / Total Assets)

$(0,597 \times 0,115)+(0,066 \times 0,09) \approx 0,075$ (Own resources / Total Active)

$(0,597 \times 0,619)+(0,066 \times 0,532) \approx 0,405$ (Total Deposits / Total Assets)

In order for to Şeker Bank to be effective, it should take resemble of Ziraat Bank by $\% 60$ and Alternative Bank by $\% 7$.

\section{TEB}

\begin{tabular}{|c|c|c|c|c|}
\hline $\begin{array}{c}\text { Technical } \\
\text { Efficiency }\end{array}$ & \multicolumn{4}{|c|}{$\mathbf{0 , 7 7 2}$} \\
\hline Variables & $\begin{array}{c}\text { Original } \\
\text { Value }\end{array}$ & $\begin{array}{c}\text { Radial } \\
\text { Movement }\end{array}$ & $\begin{array}{c}\text { Slack } \\
\text { Movement }\end{array}$ & $\begin{array}{c}\text { Projected } \\
\text { Value }\end{array}$ \\
\hline ROA & 0,010 & 0,000 & 0,000 & 0,010 \\
\hline ROE & 0,105 & 0,000 & 0,000 & 0,105 \\
\hline $\begin{array}{c}\text { Personnel Expenses / } \\
\text { Total Assets }\end{array}$ & 0,013 & $-0,003$ & 0,000 & 0,010 \\
\hline $\begin{array}{c}\text { Total Loans/Total } \\
\text { Assets }\end{array}$ & 0,721 & $-0,165$ & $-0,003$ & 0,554 \\
\hline Equity / Total Assets & 0,094 & $-0,021$ & 0,000 & 0,072 \\
\hline $\begin{array}{c}\text { Total Deposits / } \\
\text { Total Assets }\end{array}$ & 0,626 & $-0,143$ & $-0,062$ & 0,421 \\
\hline
\end{tabular}

\begin{tabular}{|c|c|}
\hline Peer & Lambda Weight \\
\hline Fibabanka & 0,002 \\
Ziraat Bankas1 & 0,109 \\
\hline Alternatif Bank & 0,662 \\
\hline
\end{tabular}

Table 9: TEB CCR analysis 
18 E. Balc1, and B. Ayvaz/ Southeast Europe Journal of Soft Computing Vol.9 No.1 March 2020 (9-23)

Target Value Calculation;

$(0,002 \times 0,014)+(0,109 \times 0,007)+(0,662 \times 0,014) \approx 0,010$ (Personnel Expenses / Total Assets)

$(0,002 \times 0,770)+(0,109 \times 0,573)+(0,662 \times 0,740) \approx 0,554$ (Total Loans / Total Assets)

$(0,002 \times 0,073)+(0,109 \times 0,115)+(0,662 \times 0,09) \approx 0,072$ (Own resources / Total Active)

$(0,002 \times 0,652)+(0,109 \times 0,619)+(0,662 \times 0,532), 40,421$ (Total Deposits / Total Assets)

In order to activate ineffective TEB, it should take resemble of \%o2 Fibabanka, \%11 Ziraat Bank and \%66 Alternatif Bank.

\section{Garanti BBVA}

\begin{tabular}{|c|c|c|c|c|}
\cline { 2 - 5 } Technical & \multicolumn{4}{|c|}{0,973} \\
Vfficiency \\
Variables & $\begin{array}{c}\text { Original } \\
\text { Value }\end{array}$ & $\begin{array}{c}\text { Radial } \\
\text { Movement }\end{array}$ & $\begin{array}{c}\text { Slack } \\
\text { Movement }\end{array}$ & $\begin{array}{c}\text { Projected } \\
\text { Value }\end{array}$ \\
\hline ROA & 0,015 & 0,000 & 0,000 & 0,015 \\
\hline ROE & 0,123 & 0,000 & 0,000 & 0,123 \\
\hline $\begin{array}{c}\text { Personnel Expenses } \\
\text { / Total Assets }\end{array}$ & 0,009 & 0,000 & $-0,001$ & 0,007 \\
\hline $\begin{array}{c}\text { Total Loans/Total } \\
\text { Assets }\end{array}$ & 0,612 & $-0,017$ & 0,000 & 0,596 \\
\hline $\begin{array}{c}\text { Equity / Total } \\
\text { Assets }\end{array}$ & 0,119 & $-0,003$ & $-0,001$ & 0,114 \\
\hline $\begin{array}{c}\text { Total Deposits / } \\
\text { Total Assets }\end{array}$ & 0,550 & $-0,015$ & 0,000 & 0,535 \\
\hline
\end{tabular}

\begin{tabular}{|c|c|}
\hline Peer & Lambda Weight \\
\hline Akbank & 0,797 \\
\hline Ziraat Bankas1 & 0,086 \\
Alternatif Bank & 0,078 \\
\hline
\end{tabular}

Table 10: Garanti BBVA CCR analysis

Target Value Calculation;

$(0,797 \times 0,007)+(0,086 \times 0,007)+(0,078 \times 0,014) \approx 0,007$ (Personnel Expenses / Total Assets)

$(0,797 \times 0,613)+(0,086 \times 0,573)+(0,078 \times 0,740) \approx 0,596$ (Total Loans / Total Assets)

$(0,797 \times 0,122)+(0,086 \times 0,115)+(0,078 \times 0,09) \approx 0,114$ (Own resources / Total Active)

$(0,797 \times 0,552)+(0,086 \times 0,619)+(0,078 \times 0,532) \approx 0,535$ (Total Deposits / Total Assets)

In order for Garanti BBVA to be effective, it should take resemble of Akbank by $\% 80$, Ziraat Bank by $\% 9$,and Alternative Bank by $\% 8$.

\section{Halk Bankası}

\begin{tabular}{|c|c|c|c|c|}
\hline $\begin{array}{c}\text { Techical } \\
\text { Efficiency } \\
\text { Variables }\end{array}$ & $\begin{array}{c}\text { Original } \\
\text { Value }\end{array}$ & $\begin{array}{c}\text { Radial } \\
\text { Movement }\end{array}$ & $\begin{array}{c}\text { Slack } \\
\text { Movement }\end{array}$ & $\begin{array}{c}\text { Projected } \\
\text { Value }\end{array}$ \\
\hline ROA & 0.014 & 0.000 & 0.000 & 0.015 \\
\hline ROE & 0.133 & 0.000 & 0.000 & 0.133 \\
\hline $\begin{array}{c}\text { Personnel Expenses } \\
\text { / Total Assets } \\
\text { Total Loans/Total } \\
\text { Assets }\end{array}$ & 0.008 & 0.000 & 0.000 & 0.008 \\
\hline $\begin{array}{c}\text { Equity / Total } \\
\text { Assets }\end{array}$ & 0.106 & -0.002 & 0.000 & 0.104 \\
\hline $\begin{array}{c}\text { Total Deposits / } \\
\text { Total Assets }\end{array}$ & 0.667 & -0.012 & -0.060 & 0.595 \\
\hline
\end{tabular}

\begin{tabular}{|c|c|}
\hline Peer & Lambda Weight \\
\hline Akbank & 0,797 \\
\hline Ziraat Bankas1 & 0,086 \\
\hline Alternatif Bank & 0,078 \\
\hline
\end{tabular}

\section{Table 11: Halk Bankası CCR analysis}

Calculation of target value;

$(0,131 \times 0,014)+(0,823 \times 0,007) \approx 0,008$ (Personnel Expenses / Total Assets)

$(0,131 \times 0,770)+(0,823 \times 0,573) \approx 0,573($ Total Loans $/$ Total Assets)

$(0,131 \times 0,073)+(0,823 \times 0,115) \approx 0,104$ (Equity / Total Assets)

$(0,131 \times 0,652)+(0,823 \times 0,619) \approx 0,595$ (Total Deposits / Total Assets)

In order for Halk Bank to be effective, it should take resemble of Fibabank by $\% 13$ and Ziraat Bank by $\% 82$.

\section{İş Bankası}

\begin{tabular}{|c|c|c|c|c|}
\hline $\begin{array}{c}\text { Technical } \\
\text { Efficiency } \\
\text { Variables }\end{array}$ & $\begin{array}{c}\text { Original } \\
\text { Value } \\
0.014\end{array}$ & $\begin{array}{c}\text { Radial } \\
\text { Movement } \\
0.000\end{array}$ & $\begin{array}{c}\text { Slack } \\
\text { Movement } \\
0.000\end{array}$ & $\begin{array}{c}\text { Projected } \\
\text { Value } \\
0.014 \\
\text { ROA }\end{array}$ \\
ROE & 0.115 & 0.000 & 0.001 & 0.117 \\
\hline $\begin{array}{c}\text { Personnel Expenses } \\
\text { / Total Assets } \\
\text { Total Loans/Total } \\
\text { Assets }\end{array}$ & 0.010 & -0.001 & -0.003 & 0.006 \\
\hline $\begin{array}{c}\text { Equity / Total } \\
\text { Assets }\end{array}$ & 0.123 & -0.011 & 0.000 & 0.112 \\
\hline $\begin{array}{c}\text { Total Deposits / } \\
\text { Total Assets }\end{array}$ & 0.562 & -0.050 & 0.000 & 0.512 \\
\hline
\end{tabular}

\begin{tabular}{|c|c|}
\hline Peer & Lambda Weight \\
Akbank & 0,875 \\
\hline Ziraat Bankasi & 0,048 \\
\hline
\end{tabular}

Table 12: İş Bankası CCR analysis 
19 E. Balc1, and B. Ayvaz/ Southeast Europe Journal of Soft Computing Vol.9 No.1 March 2020 (9-23)

Target Value Calculation;

$(0,875 \times 0,007)+(0,048 \times 0,007) \approx 0,006($ Personnel Expenses / Total Assets)

$(0,875 \times 0,573)+(0,048 \times 0,613) \approx 0,564$ (Total Loans / Total Assets)

$(0,875 \times 0,115)+(0,048 \times 0,122) \approx 0,112($ Own resources / Total Active)

$(0,875 \times 0,619)+(0,048 \times 0,552) \approx 0,512$ (Total Deposits / Total Assets)

In order to activate the ineffective Turkiye Is Bankasi, it must be $88 \%$ to Akbank and 5\% similar to Ziraat Bankası.

\section{Vakıf Bank}

\begin{tabular}{|c|c|c|c|c|}
\hline $\begin{array}{c}\text { Technical } \\
\text { Efficiency }\end{array}$ & \multicolumn{4}{|c|}{$\mathbf{0 . 9 7 1}$} \\
\hline Variables & $\begin{array}{c}\text { Original } \\
\text { Value }\end{array}$ & $\begin{array}{c}\text { Radial } \\
\text { Movement }\end{array}$ & $\begin{array}{c}\text { Slack } \\
\text { Movement }\end{array}$ & $\begin{array}{c}\text { Projected } \\
\text { Value }\end{array}$ \\
\hline $\begin{array}{c}0.011 \\
\text { ROA }\end{array}$ & $\begin{array}{l}0.000 \\
\text { ROE }\end{array}$ & $\begin{array}{c}0.002 \\
0.119\end{array}$ & $\begin{array}{c}0.013 \\
0.000\end{array}$ \\
\hline $\begin{array}{c}\text { Personnel Expenses } \\
\text { / Total Assets }\end{array}$ & 0.008 & 0.000 & 0.000 & 0.008 \\
\hline $\begin{array}{c}\text { Total Loans/Total } \\
\text { Assets }\end{array}$ & 0.661 & -0.019 & -0.113 & 0.529 \\
\hline $\begin{array}{c}\text { Equity / Total } \\
\text { Assets } \\
\text { Total Deposits / } \\
\text { Total Assets }\end{array}$ & 0.093 & -0.003 & 0.000 & 0.091 \\
\hline
\end{tabular}

\begin{tabular}{|c|c|}
\hline Peer & Lambda Weight \\
\hline Fibabanka & 0,191 \\
\hline Ziraat Bankas1 & 0,666 \\
\hline
\end{tabular}

Table 13: VakıfBank CCR analysis

Target Value Calculation;

$(0,191 \times 0,014)+(0,666 \times 0,007) \approx 0,008$ (Personnel Expenses / Total Assets)

$(0,191 \times 0,770)+(0,666 \times 0,573) \approx 0,529($ Total Loans $/$ Total Assets)

$(0,191 \times 0,073)+(0,666 \times 0,115) \approx 0,091$ (Equity / Total Active)

$(0,191 \times 0,652)+(0,666 \times 0,619) \approx 0,537$ (Total Deposits / Total Assets)

In order to activate Vakıfbank, which is not effective, it must resemble Fibabanka at $19 \%$ and Ziraat Bankası at $67 \%$.

\section{Yapı Kredi Bankası}

\begin{tabular}{|c|c|c|c|c|}
\hline $\begin{array}{c}\text { Technical } \\
\text { Efficiency }\end{array}$ & \multicolumn{4}{|c|}{$\mathbf{0 . 7 1 1}$} \\
\hline Variables & $\begin{array}{c}\text { Original } \\
\text { Value }\end{array}$ & $\begin{array}{c}\text { Radial } \\
\text { Movement }\end{array}$ & $\begin{array}{c}\text { Slack } \\
\text { Movement }\end{array}$ & $\begin{array}{c}\text { Projected } \\
\text { Value }\end{array}$ \\
\hline
\end{tabular}

\begin{tabular}{|c|c|c|c|c|}
\hline ROA & 0.010 & 0.000 & 0.000 & 0.011 \\
\hline ROE & 0.096 & 0.000 & 0.000 & 0.096 \\
\hline $\begin{array}{c}\text { Personnel Expenses } \\
\text { / Total Assets }\end{array}$ & 0.009 & -0.002 & 0.000 & 0.006 \\
\hline $\begin{array}{c}\text { Total Loans/Total } \\
\text { Assets }\end{array}$ & 0.673 & -0.195 & -0.058 & 0.421 \\
\hline $\begin{array}{c}\text { Equity / Total } \\
\text { Assets }\end{array}$ & 0.106 & -0.031 & 0.000 & 0.075 \\
\hline $\begin{array}{c}\text { Total Deposits / } \\
\text { Total Assets }\end{array}$ & 0.580 & -0.168 & 0.000 & 0.412 \\
\hline
\end{tabular}

\begin{tabular}{|c|c|}
\hline Peer & Lambda Weight \\
\hline Alternatif Bank & 0,154 \\
\hline Ziraat Bankasi & 0,526 \\
\hline Fibabanka & 0,007 \\
\hline
\end{tabular}

\section{Table 14: Yapı Kredi Bankası CCR analysis}

Target Value Calculation;

$(0,154 \times 0,014)+(0,526 \times 0,007)+(0,007 \times 0,014) \approx 0,006$ (Personnel Expenses / Total Assets)

$(0,154 \times 0,74)+(0,526 \times 0,573)+(0,007 \times 0,770), 40,421$

(Total Loans / Total Assets)

$(0,154 \times 0,09)+(0,526 \times 0,115)+(0,007 \times 0,073) \approx 0,075$

(Own resources / Total Active)

$(0,154 \times 0,532)+(0,526 \times 0,619)+(0,007 \times 0,652), 40,412$ (Total Deposits / Total Assets)

In order to activate ineffective Yapi Kredi Bankas1, it should resemble Alternatifbank by \%15, Ziraat Bankası by \%53, and Fibabanka by $7 \%$.

\subsection{Malmquist Total Factor Productivity Results}

TEC: Technical Efficiency

TE: Technological Efficiency

PTE: Pure Technical Efficiency

SE: Scale Efficiency

TFP: Total Factor Productivity Index

\begin{tabular}{|c|c|c|c|c|c|}
\hline 2014-2015 & TEC & TE & PTE & SE & TFP \\
\hline Akbank & 0.779 & 1.045 & 1.000 & 0.779 & 0.814 \\
\hline Alternatif Bank & 0.501 & 1.034 & 1.000 & 0.501 & 0.519 \\
\hline Burgan Bank & 6.682 & 1.110 & 0.991 & 6.742 & 7.416 \\
\hline Deniz Bank & 0.756 & 1.095 & 1.000 & 0.756 & 0.828 \\
\hline Fibabanka & 0.540 & 0.989 & 0.900 & 0.600 & 0.534 \\
\hline ING & 0.503 & 1.054 & 1.000 & 0.503 & 0.530 \\
\hline Qnb Finansbank & 0.670 & 1.068 & 0.985 & 0.680 & 0.716 \\
\hline Şekerbank & 0.379 & 1.135 & 1.013 & 0.374 & 0.430 \\
\hline TEB & 1.081 & 1.091 & 1.043 & 1.036 & 1.179 \\
\hline Ziraat Bankas1 & 1.000 & 1.108 & 1.000 & 1.000 & 1.108 \\
\hline
\end{tabular}


20 E. Balc1, and B. Ayvaz/ Southeast Europe Journal of Soft Computing Vol.9 No.1 March 2020 (9-23)

\begin{tabular}{|c|c|c|c|c|c|}
\hline Garanti BBVA & 0.898 & 1.004 & 1.000 & 0.898 & 0.901 \\
\hline Halk Bankası & 0.747 & 1.212 & 0.957 & 0.781 & 0.905 \\
İş Bankası & 0.794 & 1.012 & 1.010 & 0.786 & 0.804 \\
\hline Vakıfbank & 0.823 & 1.202 & 1.000 & 0.823 & 0.990 \\
\hline $\begin{array}{c}\text { Yapı Kredi } \\
\text { Bankası }\end{array}$ & 0.745 & 1.130 & 1.016 & 0.733 & 0.842 \\
\hline $\begin{array}{c}\text { GEOMETRIC } \\
\text { MEAN }\end{array}$ & $\mathbf{0 . 8 1 7}$ & $\mathbf{1 . 0 8 4}$ & $\mathbf{0 . 9 9 4}$ & $\mathbf{0 . 8 2 2}$ & $\mathbf{0 . 8 8 5}$ \\
\hline
\end{tabular}

Table 15: Results of MTFP analysis for 2014-2015

\begin{tabular}{|c|c|c|c|c|c|}
\hline 2015-2016 & TEC & TE & PTE & SE & TFP \\
\hline Akbank & 1.272 & 1.058 & 1.000 & 1.272 & 1.346 \\
\hline Alternatif Bank & 0.121 & 1.017 & 1.000 & 0.121 & 0.123 \\
\hline Burgan Bank & 1.492 & 1.017 & 1.126 & 1.325 & 1.517 \\
Deniz Bank & 1.347 & 1.013 & 1.000 & 1.347 & 1.365 \\
\hline Fibabanka & 1.232 & 1.017 & 1.104 & 1.116 & 1.253 \\
\hline ING & 4.045 & 1.034 & 1.000 & 4.045 & 4.183 \\
\hline Qnb Finansbank & 1.550 & 1.040 & 1.052 & 1.474 & 1.611 \\
\hline Şekerbank & 1.160 & 1.029 & 0.920 & 1.261 & 1.194 \\
TEB & 0.927 & 1.017 & 0.968 & 0.958 & 0.942 \\
\hline Ziraat Bankas1 & 1.000 & 1.069 & 1.000 & 1.000 & 1.069 \\
Garanti BBVA & 1.145 & 1.128 & 1.000 & 1.145 & 1.292 \\
Halk Bankası & 1.113 & 1.017 & 1.038 & 1.072 & 1.131 \\
\hline İş Bankası & 1.203 & 1.101 & 0.991 & 1.214 & 1.324 \\
Vakıfbank & 1.216 & 1.017 & 1.000 & 1.216 & 1.236 \\
\hline Yapı Kredi Bankas1 & 1.285 & 1.029 & 0.949 & 1.355 & 1.322 \\
\hline GEOMETRIC & $\mathbf{1 . 1 2 8}$ & $\mathbf{1 . 0 4 0}$ & $\mathbf{1 . 0 0 9}$ & $\mathbf{1 . 1 1 9}$ & $\mathbf{1 . 1 7 3}$ \\
\hline MEAN & & &
\end{tabular}

Table 16: Results of MTFP analysis for 2015-2016

\begin{tabular}{|c|c|c|c|c|c|}
\hline 2016-2017 & TEC & TE & PTE & SE & TFP \\
\hline Akbank & 1.010 & 1.057 & 1.000 & 1.010 & 1.067 \\
\hline Alternatif Bank & 4.323 & 1.166 & 1.000 & 4.323 & 5.041 \\
\hline Burgan Bank & 0.950 & 1.097 & 1.000 & 0.950 & 1.042 \\
\hline Deniz Bank & 1.121 & 0.935 & 1.000 & 1.121 & 1.048 \\
\hline Fibabanka & 1.263 & 1.166 & 1.006 & 1.255 & 1.473 \\
\hline ING & 1.235 & 1.021 & 1.000 & 1.235 & 1.261 \\
\hline Qnb Finansbank & 1.083 & 1.012 & 1.000 & 1.083 & 1.095 \\
\hline Şekerbank & 0.931 & 1.059 & 1.190 & 0.783 & 0.986 \\
\hline TEB & 0.913 & 1.028 & 0.945 & 0.966 & 0.939 \\
\hline Ziraat Bankas1 & 1.000 & 1.017 & 1.000 & 1.000 & 1.017 \\
\hline Garanti BBVA & 1.000 & 1.103 & 1.000 & 1.000 & 1.103 \\
\hline Halk Bankası & 1.163 & 1.136 & 1.016 & 1.144 & 1.321 \\
\hline İş Bankas1 & 0.910 & 1.057 & 1.002 & 0.909 & 0.962 \\
\hline Vakıfbank & 1.029 & 1.144 & 1.000 & 1.029 & 1.177 \\
\hline Yapı Kredi Bankas1 & 1.121 & 1.008 & 1.062 & 1.055 & 1.130 \\
\hline $\begin{array}{c}\text { GEOMETRIC } \\
\text { MEAN }\end{array}$ & $\mathbf{1 . 1 5 0}$ & $\mathbf{1 . 0 6 5}$ & $\mathbf{1 . 0 1 4}$ & $\mathbf{1 . 1 3 5}$ & $\mathbf{1 . 2 2 5}$ \\
\hline
\end{tabular}

Table 17: Results of MTFP analysis for 2015-2016

\begin{tabular}{|c|c|c|c|c|c|}
\hline $2017-2018$ & TEC & TE & PTE & SE & TFP \\
\hline Akbank & 1.000 & 0.902 & 1.000 & 1.000 & 0.902 \\
Alternatif Bank & 3.557 & 0.997 & 1.000 & 3.557 & 3.547 \\
\hline Burgan Bank & 1.167 & 1.061 & 1.000 & 1.167 & 1.238 \\
\hline Deniz Bank & 0.968 & 1.004 & 0.929 & 1.042 & 0.972 \\
Fibabanka & 1.189 & 1.178 & 1.000 & 1.189 & 1.401 \\
\hline ING & 1.000 & 0.967 & 1.000 & 1.000 & 0.967 \\
\hline Qnb Finansbank & 1.135 & 1.091 & 1.000 & 1.135 & 1.239 \\
\hline Şekerbank & 0.856 & 1.073 & 0.962 & 0.890 & 0.919 \\
\hline TEB & 0.881 & 1.006 & 1.022 & 0.862 & 0.886 \\
\hline Ziraat Bankas1 & 1.000 & 0.860 & 1.000 & 1.000 & 0.860 \\
\hline Garanti BBVA & 1.000 & 0.917 & 1.000 & 1.000 & 0.917 \\
\hline Halk Bankas1 & 0.685 & 0.930 & 1.000 & 0.685 & 0.636 \\
İş Bankas1 & 1.164 & 0.947 & 0.975 & 1.194 & 1.103 \\
\hline Vakıfbank & 1.000 & 0.939 & 1.000 & 1.000 & 0.939 \\
\hline Yapı Kredi Bankas1 & 1.057 & 0.986 & 0.974 & 1.086 & 1.043 \\
\hline GEOMETRIC & $\mathbf{1 . 0 8 6}$ & $\mathbf{0 . 9 8 7}$ & $\mathbf{0 . 9 9 1}$ & $\mathbf{1 . 0 9 6}$ & $\mathbf{1 . 0 7 2}$ \\
\hline MEAN & & &
\end{tabular}

Table 18: Results of MTFP analysis for 2017-2018

\begin{tabular}{|c|c|c|c|c|c|}
\hline $\begin{array}{c}2014-2018 \\
\text { Summary } \\
\text { Table }\end{array}$ & TEC & TE & PTE & SE & TFP \\
\hline $2014-2015$ & 0.817 & 1.084 & 0.994 & 0.822 & 0.885 \\
\hline $2015-2016$ & 1.128 & 1.040 & 1.009 & 1.119 & 1.173 \\
\hline $2016-2017$ & 1.150 & 1.065 & 1.014 & 1.135 & 1.225 \\
\hline $2017-2018$ & 1.086 & 0.987 & 0.991 & 1.096 & 1.072 \\
\hline $\begin{array}{c}\text { GEOMETRIC } \\
\text { MEAN }\end{array}$ & 1.036 & 1.043 & 1.002 & 1.034 & 1.081 \\
\hline
\end{tabular}

Table 19: Summary MTFP analysis for 2014-2018

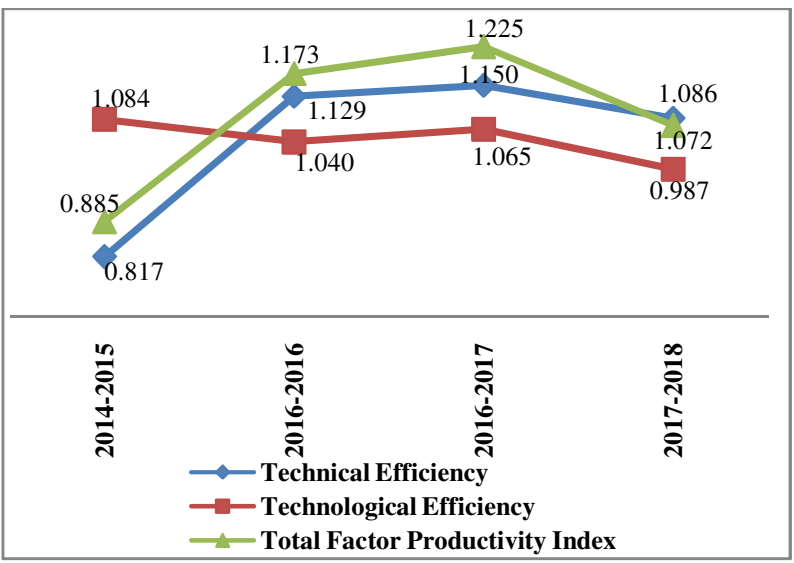

Graph2: Summary graphical representation of the MTFP analysis for 2014-2018 


\section{RESULTS}

Efficiency and productivity are improved through a better defining of the aims and processes of the performance evaluation. Through the restrictions of "envelopment", the DEA techniques combine and perfect the traditional linear programming models with the system input and output.

The banking and financial sector are key factors in the development of the national economy and play a major role in the development of the national economy.The measurement of efficiency levels in banks' performance analysis is very important both in terms of internal evaluation and evaluations of credit providers in financial markets. Banks measure performance in different ways to measure their performance and support decision makers. Data envelopment analysis and Malmquist total factor productivity index technique have been the most preferred method especially for banking sector in the analysis of efficiency and productivity concept.

In order to obtain a consistent result from the data envelopment analysis, a homogeneous group is sought and therefore some banks should be ignored in the research. In this study, 15 deposit banks operating in the Turkish banking sector were examined and expert opinion was obtained that these banks operate similar to each other and are homogeneous. The efficiency of banks was measured by using continuous annual data in the 2014-2018 period. Then, the change in the efficiency of banks on a yearly basis was examined. In this study, 4 input and 2 output variables were used. In the analysis, input-oriented data envelopment analysis model was used under the assumption of constant return to scale, and then Malmquist total factor change index was used. Results were evaluated according to mediation approach.

The efficiency results of the 15 deposit banks analyzed according to the input-oriented CCR model led to the conclusion that large-scale banks are not always the most efficient banks. The active average between 2014-2018 is in descending order; Although Ziraat Bankası, Is Bankası, Garanti BBVA, Akbank, Yapı Kredi Bankası, Halk Bankası, Vakif Bank, Qnb Finansbank, Deniz Bank, TEB, ING, Şeker Bank, AlternatifBank, Fibabanka, BurganBank.

Akbank, Fibabanka and Ziraat Bankası are equal and show the highest technical efficiency, while the decreasing ranking is followed by the following banks; Halk Bankası, Garanti BBVA, Vakıf Bank, İş Bankası, Deniz Bank, Finansbank, TEB, Yapı Kredi Bankası, Şeker Bank, ING, Burgan Bank.

In the process covering the years 2014-2018, the changes observed in Malmquist index of 15 banks, technical efficiency, technological efficiency, efficiency, pure efficiency, scale efficiency and total factor productivity were examined as a whole and it was observed that the increase in total factor productivity index was the highest in the 2016-
2017 period. The total factor productivity index was calculated with the Win4Deap program and calculated by the geometric mean method for each bank. MTFP decreased by $11.5 \%$ in 2015 compared to 2014 , increased by $17.3 \%$ in 2016 compared to 2015, increased by $22.5 \%$ in 2017 compared to 2016 and increased by $7.2 \%$ in 2018 compared to 2017. In this case, 2017 was the year in which the increase was best compared to the previous year. When MTFP is examined, it can be said that scale efficiency and technological efficiency have a significant effect.

This study was produced from my thesis titled "Bankacılıkta Veri Zarflama Analizi Ve Malmquıst Endeksi Yaklaşımı Ile Etkinlik Ve Verimlilik Analizi" which I am continuing in the Industrial Engineering Master Program of Istanbul Commerce University Institute of Science.

\section{REFERENCES}

[1] Akyüz, Yılmaz, Yıldız, F., Kaya Z. "Veri Zarflama Analizi (VZA) ve Malmquist Endeksi ile Toplam Faktör Verimlilik Ölçümü: BISST'te İşlem Gören Mevduat Bankaları Üzerine Bir Uygulama”. Atatürk Üniversitesi İktisadi ve İdari Bilimler Dergisi, s. 4 (2013): 110-130.

[2] Ariff ve Can, 2008 M. Ariff, L. CanCost and profit efficiency of Chinese banks: A non-parametric analysis China Economic Review, 19 (June (2)) (2008), syf. 260-273

[3] Asmild, M., Paradi, J.C., Aggarwall, V., Schaffnit, C., 2004. Combining DEA Window Analysis with the Malmquist Index Approach in a Study of the Canadian Banking Industry. Journal of Productivity Analysis 21, 1, 67-89

[4] Atan, M. (2003). “Türkiye Bankacıllk Sektöründe Veri Zarflama Analizi İle Bilançoya Dayalı Mali Etkinlik ve Verimlilik Analizi”. Ekonomik Yaklaşım Dergisi, 48(14), syf. $71-86$.

[5] Bakırcı, F., Sektörel Bazda Bir Etkinlik Ölçümü: VZA ile Bir Analiz. Atatürk Üniversitesi İktisadi ve İdari Bilimler Dergisi, 20 (2), 199-217 (2006).

[6] Banker, R. D., Charnes, A., and Cooper, W. W.: Some Models for Estimating Technical and Scale Inefficiencies in Data Envelopment Analysis. Management Science 30 (1984), 1078-1092.

[7] Boussofiane A, Dyson RG, Thanassoulis E. Applied data envelopment analysis. European Journal of Operational Research 1991;52:1-15.

[8] C. M. Dikmen,J. B. Reade, Factorisation of positive definite operators, Arch. Math., 91 4, p. 339-343, (2008).

[9] Ceretta,Niederauer, 2001 P.S. Ceretta, C.A.P. Niederauer Rentabilidade e eficiência no setor bancário brasileiro 
22 E. Balc1, and B. Ayvaz/ Southeast Europe Journal of Soft Computing Vol.9 No.1 March 2020 (9-23)

Revista de Administração Contemporânea (RAC), 5 (3) (2001), syf. 7-26.

[10] Charnes A., Cooper, W. W., Lewin, A. Y., and Seiford L. M.: Data Envelopment Analysis: Theory, Methodology and Applications. Springer-Verlag, New York, 1995.

[11] Charnes, A., \& Cooper, W. W. (1962). Programming with linear fractional functionals. Naval Research Logistics, 9(September (3-4)), 181-186.

[12] Charnes, A., Cooper, W. W., and Rhodes, E.: Measuring the Efficiency of Decision Making Units. European Journal of Operational Research 2 (1978), 429444.

[13] Coelli, T.J., 1996. A Guide to DEAP Version 2.1: A Data Envelopment Analysis (Computer) Program, CEPA Working Paper 96/8, Department of Econometrics, University of New England, Armidale NSW Australia.

[14] Cooper, R.G., 2001. Winning at New ProductsAccelerating the Process from Idea to Launch, third ed. Perseus Publishing, Cambridge, MA.

[15] Cooper, W.W., Seiford, L.M., Tone, K., 2000. Data Envelopment Analysis. Kluwer Academic Publishers, Boston.

[16] Çelik, Ş., Öncü, E., \& Yenice, S. (2018). Türkiye'deki Bankaların Karşılaştırmalı Etkinlik Analizi. İşletme Araştırmaları Dergisi, 10 (1), 156-171.

[17] Drake et. al., 2009 L. Drake, M.J. Hall, R. SimperBank modelling methodologies: A comparative non-parametric analysis of efficiency in the Japanese banking sector Journal of International Financial Markets, Institutions and Money, 19 (February (1)) (2009), pp. 1-15

[18] Dyson, R.G., Allen, R., Camanho, A.S., Podinovski, V.V., Sarrico, C.S., Shale, E.A., 2001. Pitfalls and protocols in DEA. European Journal of Operational Research 132, $242-259$.

[19] Fare, R., S. Grosskopf, M. Norris and Z. Zhang, "Productivity Growth, Technical Progress, and Efficiency Change in Industrialized Countries, The American Economic Review, 84, (1994), 66-83.

[20] Havrylchyk, 2006 O. Havrylchyk Efficiency of the Polish banking industry: Foreign versus domestic banks Journal of Banking Finance, 30 (July (7)) (2006), syf. 19751996.

[21] Henriques, I. C., Sobreiro, V. A., Kimura, H., \& Mariano, E. B. (2018). Efficiency in the brazilian banking system using data envelopment analysis. Future Business Journal, 4(2), 157-178.

[22]

Kamarudin.et.al.,

2015.F. Kamarudin, F. Sufian, A. Nassir, N. AnwarTechnica

1 efficiency and returns to scale on banking sector: Empirical evidence from gcc countries Pertanika Journal of Social Science Humanities, 23 (2015), pp. 219-236 (09)

[23]

Kamarudin

et.al.,

2017.F. Kamarudin,Z.H. Chiun, F. Sufian, N.A.M. AnwarD oes productivity of Islamic banks endure progress or regress?: Empirical evidence using data envelopment analysis based Malmquist Productivity Index Humanomics, 33 (1) (2017), pp. 84-118

[24] Kumar ve Gulati, 2009 S. Kumar, R. GulatiMeasuring efficiency, effectiveness and performance of Indian public sector banks International Journal of Productivity and Performance Management, 59 (December (1)) (2009), page. 51-74

[25] Küçükaksoy İ., Önal S. (2013). “Türk Bankacılık Sektöründe Faaliyet Gösteren Bankaların Etkinliklerinin Veri Zarflama Analizi Yöntemi ile Ölçülmesi: 2004-2011 Yılları Uygulaması", İstanbul Üniversitesi İktisat Fakültesi Dergisi Ekonometri ve İstatistik Dergisi, Sayı: 18, ss: 56-80.

[26] Kwon and Lee, 2015 H.-B. Kwon, J. LeeTwo-stage production modeling of large U.S. banks: A DEA-neural network approach Expert Systems with Applications, 42 (November (19)) (2015), pp. 6758-6766.

[27] Lin et. al., 2009 T.T. Lin, C.-C. Lee, T.F. ChiuApplication of DEA in analyzing a bankś operating performance Expert Systems with Applications, 36 (July (5)) (2009), pp. 8883-8891

[28] Lorcu, F. (2010), "Malmquist Toplam Faktör Verimlilik Endeksi: Türk Otomotiv Sanayi Uygulaması", İstanbul Üniversitesi İşletme Fakültesi Dergisi, 39 (2), ss. 276-289.

[29] Luo, 2003 X. LuoEvaluating the profitability and marketability efficiency of large banks: An application of data envelopment analysis Journal of Business Research, 56 (1) (2003), page. 627-635.

[30] Perico et. al. 2008A.E. Périco, D.A.d.N. Rebelatto, N.B.a. SantanaEficiên cia bancária: Os maiores bancos são os mais eficientes? Uma análise por envoltória de dados Gestão Produção, 15 (2) (2008), syf. 421-431.

[31] R.Kök, N. Şimşek, Endüstri-içi Dış Ticaret, Patentler ve Uluslar arası Teknolojik Yayılma. UEK-TEK, Uluslar arası Ekonomi Konferansı, Türkiye Ekonomi Kurumu, Ankara, (2006).

[32] Repkova, 2014 I. Repkova Efficiency of the Czech banking sector employing the DEA window analysis approach Procedia Economics and Finance, 12 (1) (2014), s. $587-596$

[33] RezitisAnthony N., Productivity Growth in the Grek Banking Industry: A Nonparametric Approach. Journal of Applied Economics, IX, 1, 119-138 (2006). 
23 E. Balc1, and B. Ayvaz/ Southeast Europe Journal of Soft Computing Vol.9 No.1 March 2020 (9-23)

[34] San-Jose et al., 2014 L. SanJose, J.L. Retolaza, J. Torres Prueñonosa Efficiency in Spanish banking: A multistakeholder approach analysis Journal of International Financial Markets, Institutions and Money, 32 (September (1)) (2014), pp. 240-255

[35] Seiford, L. M., and Thrall, R. M.: Recent developments in DEA: the mathematical programming approach to frontier analysis. Journal of Econometrics 46 (1990), 7-38.

[36] Seyrek, İ. H., \& Ata, H. A. (2010). Veri Zarflama Analizi ve Veri Madenciliği ile Mevduat Bankalarında Etkinlik Ölçümü. Journal of BRSA Banking \& Financial Markets, 4(2), 67-84.

[37] Stewart et. al., 2016.C. Stewart, R. Matousek, T.N. NguyenEfficiency in the Vietnamese banking system: A DEA double bootstrap approach Research in International Business and Finance, 36 (January (1)) (2016), pp. 96-111

[38] Svitalkova, 2014, Z. SvitalkovaComparison and evaluation of bank efficiency in selected countries in EU Procedia Economics and Finance, 12 (1) (2014), pp. 644653.

[39] Sherman, H.D. and F. Gold, 1985, Branch bank operating efficiency: Evaluation with data envelopment analysis, Journal of Banking and Finance 9, 297-315.

[40] Wanke and Barros, 2014 P. Wanke, C. BarrosTwostage DEA: An application to major Brazilian banks Expert Systems with Applications, 41 (April (5)) (2014), pp. 23372344.

[41]

Wanke et al., 2016b.P. Wanke, C. Barros, A. EmrouznejadAssessing productive efficiency of banks using integrated Fuzzy-DEA and bootstrapping: A case of Mozambican banks.

[42] Yilmaz and Günes, 2015 A. Yilmaz, N. GüneşEfficiency comparison of participation and conventional banking sectors in Turkey between 20072013.

[43] Yükçü,S., and Atağan, G. (2009). Etkinlik, etkililik ve verimlilik kavramlarının yarattığı karışıklık. Atatürk Üniversitesi İktisadi ve İdari Bilimler Dergisi, 23(4), 1-13.

[44] Zimkova, 2014 E. Zimkova Technical efficiency and super-efficiency of the banking sector in Slovakia Procedia Economics and Finance, 12 (1) (2014), pp. 780-787. 